\title{
Rectum Perforation Secondary to the Enema with Garden Hose: A Case Report
}

\author{
Bahçe Hortumu ile Lavmana Sekonder Rektum Perforasyonu: Olgu Sunumu
}

\author{
Mehmet Emin GÖNÜLLÜ \\ (D) 0000-0001-9126-2396 \\ İsmet ÖZAYDIN \\ (D) 0000-0001-9661-328X
}

Düzce University Faculty of Medicine Department of General Surgery, Düzce, Turkey

\section{Corresponding Author Sorumlu Yazar \\ Mehmet Emin GÖNÜLLÜ \\ dr.m.emin.gonullu@gmail.com}

Received / Geliş Tarihi : 22.03.2020

Accepted / Kabul Tarihi : 06.08.2020

Available Online /

Çevrimiçi Yayın Tarihi : 25.08.2020

\begin{abstract}
A 73-year-old male patient was admitted to the emergency department with severe abdominal pain. It was thought that the patient might have colon perforation with the patient's history, physical and radiological examination. In the patient's history; since his youth, it was understood that when he has been constipated, he has made an enema with tap water by attaching the garden hose into the rectum and connects the other end to the fountain. In this case report, we wanted to present the colon perforation during the hose penetration, and peritonitis of the patient who had foreign body penetration chronically into the rectum with the purpose of making enema periodically, and the operation performed after. Since our patient was a delayed case, we quickly initiated resuscitation, prophylactic antibiotherapy, and underwent protective colostomy in our operation. We think that colostomy reduces the mortality and morbidity in delayed cases.

Keywords: Rectum perforation; enema with garden hose.
\end{abstract}

ÖZ

Yetmiş üç yaşındaki bir erkek hasta acil servise şiddetli karın ağrısı şikayetiyle başvurdu. Hastanın anamnezi, fizik muayene ve radyolojik tetkikleri sonucunda kolon perforasyonu olduğu düşünüldü. Hastanın anamnezinde; gençliğinden beri, kabız kaldığında rektuma bahçe hortumu sokup hortumun diğer ucunu da çeşmeye bağlayarak çeşme suyu ile lavman yaptı̆̆ anlaşıldı. Bu vaka sunumunda, kronik olarak rektuma dönem dönem lavman yapmak amacı ile yabanc1 cisim penetrasyonu olan hastanın, hortumun penetrasyonu esnasinda kolon perforasyonu, peritonit ve sonrasında yaptığımız operasyonu sunmak istedik. Hastamız gecikmiş bir vaka olduğu için hastaya hızlı bir şekilde resüsitasyon, proflaktik antibiyoterapi başladık ve hastamıza operasyonda koruyucu kolostomi açtık. Kolostominin gecikmiş vakalarda mortalite ve morbiditeyi azalttığını düşünmekteyiz.

Anahtar kelimeler: Rektum perforasyonu; bahçe hortumu ile lavman.

\section{INTRODUCTION}

Injury of the rectum with a foreign body is frequently reported in the literature (1). Injury of the anal canal, rectum and sigmoid colon with foreign bodies has been increasing in recent years, and complications associated with some of the major emergency surgical problems (2). It is reported that patients are used foreign bodies in the rectum; for diagnostic or therapeutic purposes, and most often for sexual purposes in constipation or anorectal diseases (3). In this case report, we present a 73-year-old male patient who applied to the emergency department and had emergency intervention with the perforated rectum as a result of the pressurized water applied to the rectum for enema. 


\section{CASE REPORT}

A 73-year-old male patient applied to our emergency department with complaints of severe abdominal pain and fever. In the anamnesis of the patient; it was learned that approximately 10 hours before applying to the emergency department, he placed the garden hose for the enema he made periodically in the anus and opened the fountain and provided pressurized water. When the patient experienced constipation in the military, someone told him that he made an enema with tap water with a hose. His medical history revealed that he had chronic arterial disease and hypothyroidism and that he was receiving treatment for it. Also he had appendicitis surgery, inguinal hernia surgery, and prosthetic surgery in the knees. His physical examination was conscious-open and cooperative-orientated. Vital findings were tension arterial: $140 / 85 \mathrm{mmHg}$, fever: $37.8^{\circ} \mathrm{C}$, pulse: $108 / \mathrm{min}$-rhythmic, respiratory rate: $17 / \mathrm{min}-$ regular, oxygen saturation: $93 \%$. In the examination of the abdomen; especially prevalent mainly in the lower quadrant taken tenderness, defense and rebounds. In the rectal examination; there was blood smear on the stool, the mucosa was hyperemic, the tonus was weakened. On the chest $\mathrm{x}$-ray taken in the emergency department, free air was seen under the diaphragm (Figure 1).

In our patient's laboratory examination, a slight neutrophil increase $\left(7.8 \times 10^{3} / \mathrm{uL}\right)$ and CRP increase $(5.5 \mathrm{mg} / \mathrm{dL})$ were observed. Apart from these, we look at the biochemical and hematological parameters and that were normal. In computed tomography (CT), perforation area and fluid density were seen adjacent to the bladder of the rectum (Figure 2). After that, the informed consent form was signed by the patient and was operated and diagnostic laparotomy was performed under general anesthesia. In the rectum, about $6 \mathrm{~cm}$ proximal to the anal canal, a perforated area of about $6 \mathrm{~cm}$ and widespread fluid (tap water) were seen in the abdomen. Rectum was repaired with primary suture. A loop colostomy was created from the sigmoid colon. On the second day after the operation, the regime was started for the patient who had gas and fecal discharge. The patient was discharged on the 8th day of his hospitalization, since there were no problems in his clinical follow-up.

\section{DISCUSSION}

Regardless of the etiology, foreign bodies reaching the rectum orally or anally may lead to varying degrees of ano-rectal injury depending on the anatomical and physiological features of this region and the physical properties of the foreign body. Especially, the attempt to manually push and remove the long foreign bodies into the rectum unconsciously causes the ano-rectal region to be more traumatized (4). Among the common causes of transanal injury are; medical procedures for diagnostic or therapeutic purposes, transanal enemas, foreign bodies applied for autoeroticism, sexual assaults or falling over a sharp object (5). While foreign bodies inserted from the rectum at a young age are used for sexual purposes, they are used for fecal stoning and prostate massage in later ages (2). Most cases with rectal foreign body are men including homosexuals, elders, and patients with mental disability or victims of sexual assault in particular (7). Additionally, in drug trafficking, illicit drugs (cocaine, amphetamine and marijuana) are packed in small plastic

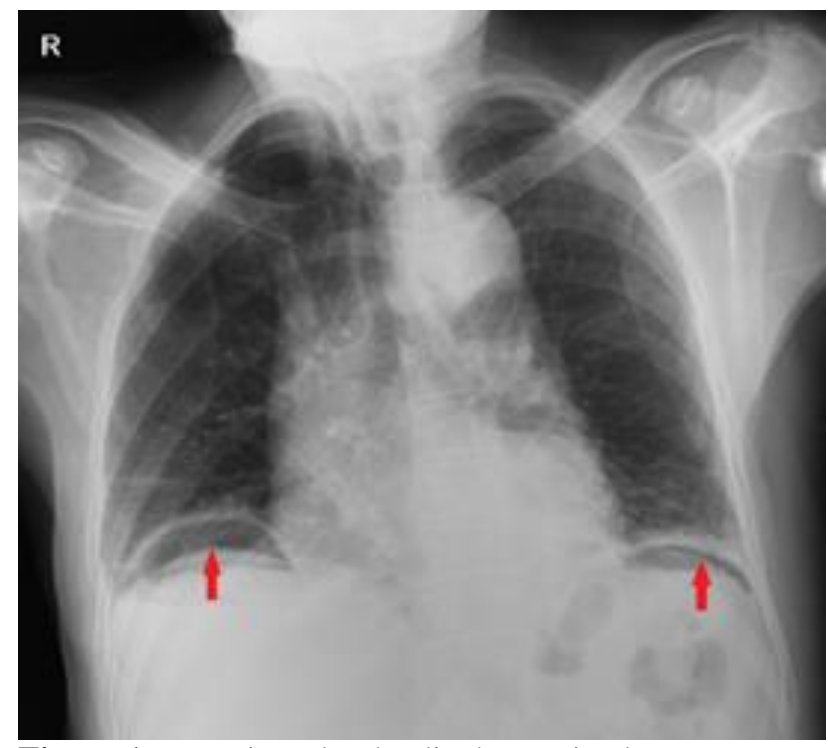

Figure 1. Free air under the diaphragm in chest X-ray
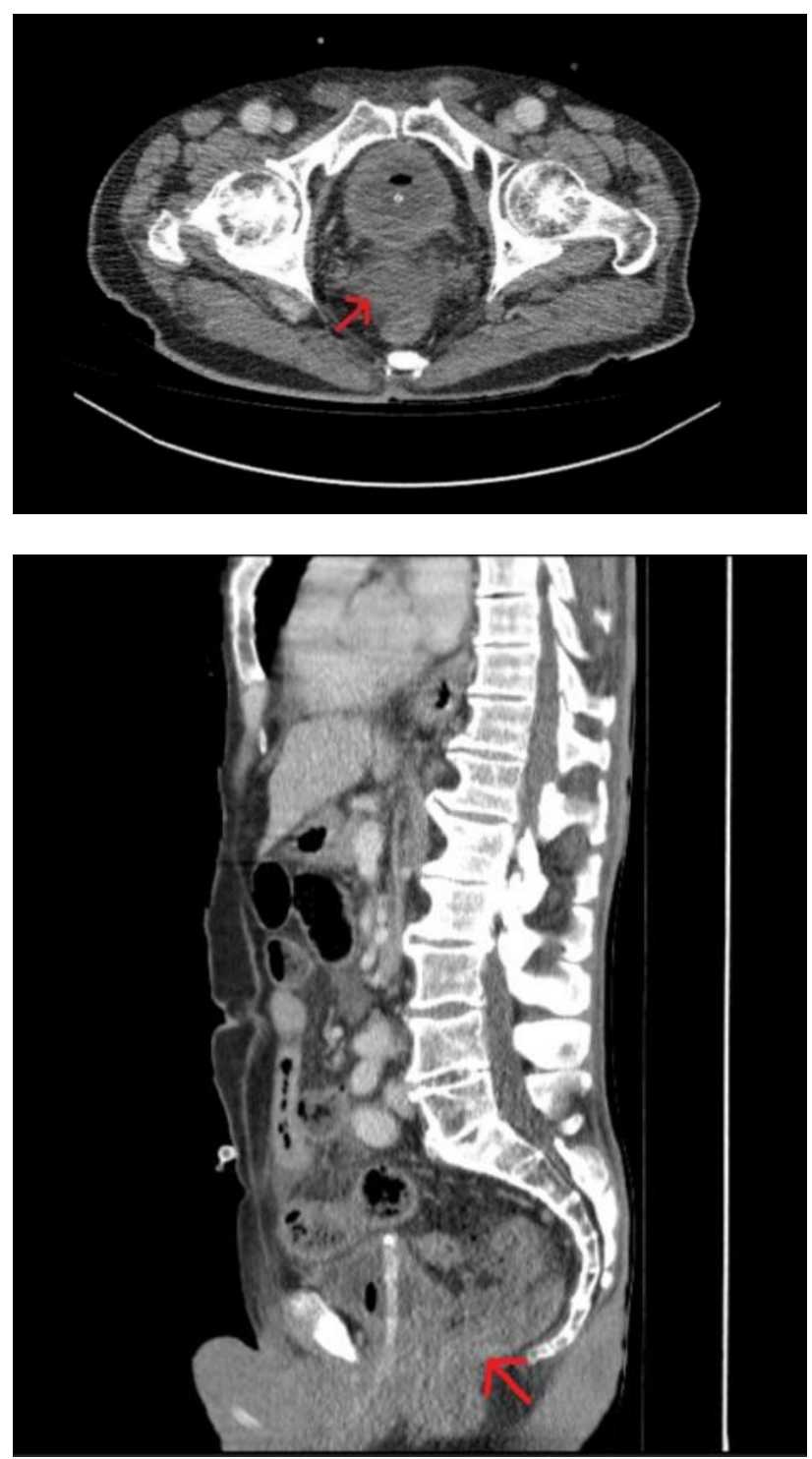

Figure 2. Computed tomography shows rectum wall irregularity and fluid density out of rectum (vertical and sagittal images) 
bags and placed in the rectum, which can be encountered. Uncommonly, objects could be lodged in the colon from perioral ingestion. Various retained objects recorded in the literature include sex toys, tools and instruments, bottles, cans, jars, poles, pipes and tubing, fruits and vegetables, stones, balls, balloons, umbrellas, light bulbs, and flashlights (8). In our patient, the etiology of the anal foreign body is the injury of the garden hose to the rectum for the purpose of enema for self-treatment.

Most of the time, a simple rectal examination is sufficient for diagnosis if suspected injury to the anal canal rectum converge. The rectal examination of blood taint or injury can be diagnosed by palpation. While intraabdominal free air seen in intraperitoneal injuries away from the anal canal makes diagnosis easier, free air may not be detected in the extraperitoneal region of the rectum. However, it should be kept in mind that in extraperitoneal rectum injuries, air can pass through the peritoneal cavity by diffusion and free air can be detected on the radiographs (5). Other organ injuries should be investigated preoperatively because of their close neighborhood in rectal foreign body injuries. $\mathrm{CT}$ is an effective method to demonstrate intra-abdominal extra organ injuries. With the CT of the patient, we saw wall irregularity in the rectum and fluid density out of the rectum and free air under the diaphragm.

The first step in the treatment of ano-rectal injuries is to provide hemodynamics and start broad-spectrum antibiotics. In our patient, we quickly start ceftriaxone $2 \times 1$ gr and metronidazole $3 \times 500 \mathrm{mg}$ after the patient's hemodynamics was corrected quickly. Then, we performed a diagnostic laparotomy immediately.

Colostomy is recommended for transanal or perianal injuries. Especially after eight hours, colostomy is of high importance for intraperitoneal rectum injuries (6). We created a colostomy as our patient was a delayed case and had extensive peritonitis.

\section{CONCLUSION}

Early and accurate diagnosis in anorectal injuries is required to reduce morbidity and mortality. For this purpose, we think that rare cases should be known and in the presence of peritoneal contamination, colostomy should not be avoided in delayed cases. It is certain that rapid diagnostic laparotomy will decrease morbidity and mortality immediately after hemodynamics has improved and broad spectrum antibiotherapy has started before surgery. In addition, we think that CT imaging has an effect on the planning of the surgery in order to separate between any other organ injuries before the surgery and to show the extent of the fluid in the abdomen.

Written informed consent form was obtained from the patient.

\section{REFERENCES}

1. Khan SA, Davey CA, Khan SA, Trigwell PJ, Chintapatla S. Munchausen's syndrome presenting as rectal foreign body insertion:a case report. Cases J. 2008;1(1):243.

2. Buluş H, Yavuz A, Koyuncu A, Sugüneş T, Akpınar A, Coşkun A. Case of unusual foreign body in the rectum. Turk J Colorectal Dis. 2010;20(4):185-7.

3. Oruç C, Uğur M, Akküçük S, Çelikel A Kılıç E, Ortanca I. Inorganic foreign body in rectum: case report. Int J Basic Clin Med. 2015;3(3):131-4.

4. Dokur M, Aydoğan B, Uysal E, Petekkaya E, Ak E. Rectal foreign body encountered in old age: a case report. Gümüşhane Uni J Health Sci. 2016;5(3):139-43.

5. Altıntoprak F. Penetrating rectum and bladder injury without perineal and sphincter damage after falling down from tree. Ege J Med. 2011;50(1):69-72

6. Kılınçaslan H, Aydoğdu İ, Kocaman O, Hasbahçeci M, Bilgin M, Alver S. A rare case of septic shock in an adolescent: rectal perforation resulting from a fall from a hammock. Med Bull Haseki. 2014;52(2):133-6.

7. Patmano M, Çetin DA, Gümüş T, Yıldırım S. A rare foreign body during colonoscopy: Headpiece of enema kit (p 493-4). Annals Med Res. 2018;25(3):493-4.

8. Mani H, Waits R. Retained colorectal foreign body: a case report. Int J Clin Med Imaging. 2018;5(7):615. 